\section{Genetic Variants in Folate and Cobalamin Metabolism-Related Genes in Nonsyndromic CleftLip and/or Palate}

Márcia Waltrick-Zambuzzi², Patricia Nivoloni Tannure ${ }^{1}$, Thays Cristine dos Santos Vieira², Leonardo Santos Antunes ${ }^{2}$, Fábio Lourenço Romano ${ }^{3}$, Willian Fernando Zambuzzi ${ }^{4}$, José Mauro Granjeiro ${ }^{2,5}$, Erika Calvano Küchler ${ }^{3}$
'Dental School, Universidade Veiga de Almeida, Rio de Janeiro, RJ, Brazil ${ }^{2}$ Clinical Research Unit, Antonio Pedro University Hospital, UFF - Universidade Federal Fluminense, Niterói, RJ, Brazil ${ }^{3}$ Department of Pediatric Clinic, School of Dentistry of Ribeirão Preto, USP - University of São Paulo, Ribeirão Preto, SP, Brazil ${ }^{4}$ Departament of Chemistry and Biochemistry, UNESP Universidade Estadual Paulista, Botucatu, SP, Brazil ${ }^{5}$ Bioengineering Program, INMETRO - Instituto Nacional de Metrologia Qualidade e Tecnologia, Xerém, RJ, Brazil

Correspondence: Erika Calvano Küchler, Avenida do Café, s/n, Monte Alegre, 14040-904, Ribeirão Preto, SP, Brasil. Tel: +55-16-3315-3995. e-mail: erikacalvano@gmail.com

Key Words: cleft lip and/or palate, vitamin B12, folic acid, MTRR gene, TCN2 gene, genetic polymorphisms, subphenotypes.

\section{Introduction}

Nonsyndromic cleft lip and/or palate (NSCL/P) is one of the most common congenital anomalies in humans and has an impact in the oral health. NSCL/P is a multifactorial condition and many factors, such as ethnical background, geographic origin, socioeconomic status, genetics and environmental factors are involved (1).

Environmental factors, such as vitamin supplementation at preconception period, have been shown to contribute in the prevention of many birth defects, especially NSCL/P (2). Folate (folic acid) and cobalamin (vitamin B12) participate in the methylation cycle and act as cofactors in DNA and RNA biosynthesis, playing an essential role in cell differentiation and tissue growth as well as during embryogenesis (3). Studies using animal models have demonstrated a specific involvement of folate and cobalamin during palatogenesis (4).

Transcobalamin II is a protein responsible for cobalamin transporting to the cells at tissues (5-8) and it is encoded by TCN2 gene. Metabolically, just after cellular uptake, cobalamin participates as a cofactor in so many biochemical pathways, including that responsible by homocysteine (Hcy) metabolism, involving methionine, a recognized methyl donor (9). This reaction is regulated by two enzymes, methionine synthase (MTR) and methionine synthase reductase (MTRR), encoded by the MTRR gene (10).

Polymorphisms in TCN2 and MTRR might alter cell metabolism during embryonic development. A previous study has proposed that $T C N 2776 \mathrm{C}>\mathrm{G}$ polymorphism may be functionally associated with NSCL/P (11). The $G$ allele is associated with lower circulating concentrations of transcobalamin (12). In addition, other studies suggested that MTRR $66 \mathrm{~A}>\mathrm{G}$ polymorphism is a risk factor for neural tube defects (13) and NSCL/P (14). This variant leads to the amino acid change of isoleucine to methionine at position 22 (15). The $\mathrm{G}$ allele produces an enzyme with less affinity for the substrate (16). Although some studies have evaluated the association between periconception use of multi-vitamin with NSCL/P $(17,18)$ only few have investigated the folate and cobalamin pathway polymorphisms in the etiology of NSCL/P.

Therefore, it is possible that polymorphisms in TCN2 and MTRR genes are involved in the NSCL/P etiology. We may hypothesize that these polymorphisms act alone or in a gene/gene interaction or gene/environmental interaction. Thus, the present study aimed to evaluate the association between NSCL/P with polymorphisms in TCN2 and MTRR genes and to evaluate the interaction between these two polymorphisms with environmental factors.

\section{Material and Methods}

\section{Subjects}

The NSCL/P group was ascertained through a public 
hospital specialized on orofacial cleft rehabilitation (Hospital Nossa Senhora do Loreto), Rio de Janeiro State, Brazil. Syndromic cleft were excluded. Also, to reduce possible etiological heterogeneity, we excluded those patients with clefts with additional unspecified multiple malformations.

The non-cleft group consisted of unrelated subjects, with no familiar history of NSCL/P that sought for a dental treatment at the Pediatric dentistry Clinic at Federal University of Rio de Janeiro (UFRJ). Both institutions are located in the city of Rio de Janeiro, geographically positioned at southeast of Brazil. Both institutions are located within $10 \mathrm{~km}$ of each other, in the same city of Rio de Janeiro. The control group was selected to ensure it matched the cleft group in age, gender, and geographic distribution. born with or without clefts since September/2009 to September/2011. All individuals or parents/legal guardians answered a questionnaire about demographic characteristics; positive family history of cleft and mothers habits (smoke and alcohol ingestion during pregnancy).

Local Research and Ethics Committee (Protocol Number 113/09) approved this study. All participating individuals or parents/legal guardians allowed participation in this study by signing an informed consent.

\section{Determination of Cleft Types}

The determination of cleft types was based on clinical examination. Cases were classified in cleft lip only, cleft lip and palate and cleft palate only. Based on cleft laterality, cases were also divided in left, right or bilateral.

\section{DNA Samples and Genotyping}

Genomic DNA was extracted from oral cells by the previously reported method (19). Genetic polymorphisms in the TCN2 gene (rs1801198) and in the MTRR gene (rs1801394) were genotyped by real-time polymerase chain reactions using the Taqman method by Agilent Technologies (Stratagene Mx3005P). All reagents and assays were supplied from Applied Biosystems (Foster City, CA, USA). Markers informations are included in Table 1.
The examiners collected all data from individuals

\section{Statistical Analysis}

Data were analyzed using the Statistical Package for the Social Sciences (SPSS - 16.0; SPSS Inc., Chicago, IL. USA)). In addition, NSCL/P group were analyzed not only as a total group, but also in stratified subgroups: cleft type (cleft lip only, clef lip and palate, and cleft palate only), mothers' smoking and drinking behavior during gestational period; cleft side and cleft completeness. Chi-square determined if NSCL/P or cleft types was preferentially associated with TCN2 or MTRR genotypes and alleles. The binary logistic regression was adjusted for genotype, ethnic groups and mothers' habits (smoke and alcohol ingestion). Gene-gene interactions were also ascertained with binary logistic regression analysis. Differences were considered significant when $p \leq 0.05$. Moreover, the standard chi-square test was used to test for deviation from Hardy-Weinberg equilibrium.

\section{Results}

Of 867 individuals included in this study, 401 were NSCL/P (case group) and 466 were non-cleft individuals (control group). The cleft lip and palate was the most common cleft type (67.3\%). The characteristics of the studied population are summarized in Table 2. Based on the maternal habits, $18.7 \%$ and $13.5 \%$ of mothers, respectively, into case group (NSCL/P) and control group (non-cleft individuals) smoked during gestational period. A significant difference was observed $(p=0.037)$ between groups. Alcohol consumption during pregnancy was not different between groups $(p=0.080)$.

Genotype distributions for both polymorphisms were in Hardy-Weinberg equilibrium. There were no significant differences in the allele and genotype distribution of TCN2 between non-cleft and NSCL/P groups. A lack of association was also observed for cleft types (Table 3). MTRR polymorphism distribution between non-cleft and NSCL/P groups is presented in the Table 4.

Alleles distributions were not associated with NSCL/P for in both studied genes ( $p>0.05$ ).

In the logistic regression analysis adjusted for genotypes and mother smoking during pregnancy, MTRRAG genotype was significantly associated $(\mathrm{p}=0.030)$ demonstrating an increased risk for NSCL/P (OR=1.439, 95\% $\mathrm{Cl} 1.035-2.000)$.

During logistic regression analysis gene-gene interaction was not observed $(p=0.258)$.

Table 1. Details on the studied genetic markers

\begin{tabular}{|c|c|c|c|c|c|c|c|}
\hline Gene & Gene name & SNP ID & $\begin{array}{c}\text { DNA } \\
\text { change }^{\mathrm{a}}\end{array}$ & $\begin{array}{l}\text { Protein } \\
\text { effect }\end{array}$ & Location & Alelles $^{b}$ & MAFc \\
\hline TCN2 & Transcobalamin 11 & rs1801198 & $776 \mathrm{C}>\mathrm{G}$ & Arg259Pro & Chr22 & {$[\mathrm{C} / \mathrm{G}]$} & 0.45 \\
\hline MTRR & $\begin{array}{c}\text { Methionine } \\
\text { synthase reductase }\end{array}$ & rs1801394 & $66 \mathrm{~A}>\mathrm{G}$ & Met22lle & Chr5 & {$[\mathrm{A} / \mathrm{G}]$} & 0.42 \\
\hline
\end{tabular}

Note: aRef. seq.:TCN2:c.M60396.1; MTRR:c.NM_002454.1. ${ }^{\text {ln }}$ In bold letters are minor allele count c Obtained from ENTREZ SNP database (http://www.ncbi.nlm.nih.gov/sites/entrez).

\section{Discussion}

A recent meta-analysis reported that folic acid, alone or in combination with vitamins and minerals, reduces birth defects but there are no evidences regarding the effects on NSCL/P prevention (20). In addition 
a previous study demonstrated that folate-related gene polymorphisms could be risk factors for NSCL/P (21). Our study analyzed the association of polymorphisms of folate-related gene (TCN2 and MTRR) with NSCL/P in a Brazilian population.

It was not found an association between TCN2 $(776 \mathrm{C}>\mathrm{G})$ and NSCL/P. Martinelli et al. (11) investigated the association between NSCL/P and TCN2 $(776 \mathrm{C}>\mathrm{G})$ gene in a case-parent triad and they suggested that this polymorphism might be functionally related with NSCL/P. On the other hand,

Table 2. Characteristics of the groups

\begin{tabular}{|c|c|c|c|}
\hline Characteristics & $\begin{array}{c}\text { NSCL/P } \\
\text { group } \\
(n=401)\end{array}$ & $\begin{array}{c}\text { Non-cleft } \\
\text { group } \\
(n=466)\end{array}$ & $\begin{array}{c}\mathrm{p} \\
\text { value }\end{array}$ \\
\hline $\begin{array}{l}\text { Mean age in } \\
\text { years (SD) }\end{array}$ & $\begin{array}{c}16.55 \\
( \pm 11.48)\end{array}$ & $20.39( \pm 15.94)$ & $0.001^{*}$ \\
\hline \multicolumn{4}{|l|}{ Sex $(\%)$} \\
\hline Male & $221(55.1)$ & $211(45.3)$ & $0.004^{* * *}$ \\
\hline Female & $180(44.9)$ & $255(54.7)$ & \\
\hline \multicolumn{4}{|l|}{ Ethnic group (\%) } \\
\hline Caucasian & $252(62.8)$ & $311(66.7)$ & $0.203^{* *}$ \\
\hline Black & $149(37.2)$ & $155(33.3)$ & \\
\hline \multicolumn{4}{|l|}{$\begin{array}{l}\text { Mothers smoking } \\
\text { during pregnancy (\%) }\end{array}$} \\
\hline Yes & $75(18.8)$ & $63(13.6)$ & $0.037^{* * *}$ \\
\hline No & $324(81.2)$ & $401(86.4)$ & \\
\hline \multicolumn{4}{|l|}{$\begin{array}{l}\text { Alcohol consumption } \\
\text { during pregnancy (\%) }\end{array}$} \\
\hline Yes & $42(10.5)$ & $33(7.1)$ & $0.080^{* * *}$ \\
\hline No & 357 (89.5) & $430(92.9)$ & \\
\hline \multicolumn{4}{|l|}{ Only NSCL/P group } \\
\hline \multicolumn{4}{|l|}{ Cleft Type (\%) } \\
\hline Cleft lip only & $71(17.7)$ & & \\
\hline Cleft lip and palate & $270(67.3)$ & & \\
\hline Cleft palate only & $60(15.0)$ & & \\
\hline \multicolumn{4}{|l|}{ Cleft side ( $\%)$} \\
\hline Bilateral cleft & $94(27.6)$ & & \\
\hline Unilateral left cleft & $172(50.5)$ & & \\
\hline Unilateral right cleft & 75 (21.9) & & \\
\hline \multicolumn{4}{|l|}{$\begin{array}{l}\text { Positive family } \\
\text { history of cleft (\%) }\end{array}$} \\
\hline Familial cases & $100(24.9)$ & & \\
\hline Sporadic cases & 301 (75.1) & & \\
\hline
\end{tabular}

*Note: Student test, ${ }^{* *}$ chi-square test $\mathrm{p} \leq 0.05$; bold forms indicated statistical significance. later studies tried to replicate their findings, but could not confirm this association (10).

This inconsistency on different results maybe explained by the ethnical background differences. New studies are necessary to evaluate this association in different populations. In our Brazilian sample group from the southeast of the country, there was no association between TCN2 gene (776 C>G) and NSCL/P types, neither geneenvironmental interaction.

Previous studies investigated MTRR gene $(66 \mathrm{~A}>\mathrm{G})$ polymorphism and reported a negative association with $\operatorname{NSCL/P}(10,11,22,23)$, although a recent study with Ukrainian individuals observed that the MTRR was associated with the NSCL/P risk (14). We found a borderline association when we analyzed the MTRR genotypes distribution in NSCL/P versus non-cleft group ( $p=0.06)$. It is important to highlight that in our subgroup analysis (according to the cleft type), there was a borderline association only for cleft lip and palate group. This could be explained by the fact that cleft lip with or without palate has a different etiological background than cleft palate only. Our results lead us to hypothesize that MTRR $(66 \mathrm{~A}>\mathrm{G})$ polymorphism plays a role in the specific NSCL/P type, the cleft lip with palate phenotype, in which this gene acts with a small effect in clefting establishment.

The logistic regression analysis suggested that smoke during pregnancy could interact with MTRR. Chemical components found in tobacco smoke possibly alter the ability of the cell to store and metabolize folate (24). For this reason, current smoking status affects dietary nutrient intake as well as plasma folate levels (25). Considering that women have a decreased folate and vitamin B12 serum concentrations during pregnancy, we hypothesize that women smokers in gestational period that carrier the polymorphic variant in MTRR gene need more vitamin supplementation.

The results of this study suggest that further investigations should be performed in order to confirm the involvement of MTRR in the etiology of NSCL/P, maybe by looking for other polymorphic loci on MTRR gene. In addition, we recommend that, in the future, the data about mother supplementation during pregnancy should be collected. The absence of these data is an obvious limitation of our study. However, the set of results obtained on this direction will bring some conclusion regarding the knowledge about the MTRRinvolvement in NSCL/P etiology.

In conclusion, the present study did not confirm that the polymorphism rs 1801198 in TCN2 is associated with NSCL/P. However our results suggested that the polymorphism rs1801394 in MTRR may be associated with the NSCL/P in a southeast Brazilian population, mainly cleft lip and palate type. 
Table 3. Frequency of TCN2 allele and genotype distribution among NSCL/P and non-clefts groups

\begin{tabular}{|c|c|c|c|c|c|c|}
\hline \multirow{2}{*}{ Subjects } & \multicolumn{3}{|c|}{ Alleles $\mathrm{n}(\%)$} & \multicolumn{2}{|c|}{ Genotypes n (\%) } & \multirow{2}{*}{$\mathrm{p}$ value } \\
\hline & C & G & $\mathrm{CC}$ & CG & GG & \\
\hline Non-clefts & $557(63.3)$ & $323(36.7)$ & $179(40.7)$ & $199(45.2)$ & $62(14.1)$ & ------ \\
\hline \multicolumn{7}{|l|}{ Cleft type } \\
\hline All Clefts & $438(61.0)$ & $280(39.0)$ & $139(38.7)$ & $160(44.6)$ & $60(16.7)$ & 0.58 \\
\hline Cleft lip only & $75(63.6)$ & $43(36.4)$ & $25(42.4)$ & $25(42.4)$ & $9(15.2)$ & 0.91 \\
\hline Cleft lip and palate & $304(61.0)$ & $194(39.0)$ & $94(37.8)$ & $116(46.5)$ & $39(15.7)$ & 0.71 \\
\hline Cleft palate only & $59(57.8)$ & $43(42.2)$ & $20(39.2)$ & $19(37.2)$ & $12(23.6)$ & 0.18 \\
\hline \multicolumn{7}{|l|}{ Cleft side } \\
\hline Bilateral & $113(62.1)$ & $69(37.9)$ & $38(41.8)$ & $37(40.7)$ & $16(17.5)$ & 0.61 \\
\hline Unilateral left & $189(63.0)$ & $111(37.0)$ & $60(40.0)$ & $69(46.0)$ & $21(14.0)$ & 0.99 \\
\hline Unilateral right & $77(57.5)$ & $57(42.5)$ & $21(31.3)$ & $35(52.2)$ & $11(16.5)$ & 0.35 \\
\hline \multicolumn{7}{|c|}{ Subgroups (only NSCL/P) } \\
\hline \multicolumn{7}{|c|}{ Mother smoking during pregnancy } \\
\hline No & $350(60.2)$ & $232(39.8)$ & $109(37.5)$ & $132(45.4)$ & $50(17.2)$ & \multirow{2}{*}{0.57} \\
\hline Yes & $86(65.2)$ & $46(34.8)$ & $29(43.9)$ & $28(42.5)$ & $9(13.6)$ & \\
\hline \multicolumn{7}{|c|}{ Alcohol consumption during pregnancy } \\
\hline No & $395(61.4)$ & $249(38.6)$ & $126(39.1)$ & $143(44.4)$ & $53(16.5)$ & \multirow{2}{*}{0.85} \\
\hline Yes & $41(58.6)$ & $29(41.4)$ & $12(34.3)$ & 17 (48.6) & $6(17.1)$ & \\
\hline
\end{tabular}

Table 4. Frequency of MTRR allele and genotype distribution among NSCL/P and non-clefts groups

\begin{tabular}{|c|c|c|c|c|c|c|}
\hline \multirow{2}{*}{ Subjects } & \multicolumn{2}{|c|}{ Alleles n (\%) } & \multicolumn{3}{|c|}{ Genotypes n (\%) } & \multirow{2}{*}{$\mathrm{p}$ value } \\
\hline & A & G & AA & $\mathrm{AG}$ & GG & \\
\hline Non-clefts & 465 (57.9) & $337(42.1)$ & $136(34.1)$ & $193(48.1)$ & $72(17.8)$ & ------ \\
\hline \multicolumn{7}{|l|}{ Cleft type } \\
\hline All Clefts & $384(56.1)$ & $300(43.9)$ & $95(27.8)$ & $194(56.7)$ & $53(15.5)$ & 0.06 \\
\hline Cleft lip only & $66(56.9)$ & $50(43.1)$ & $17(29.3)$ & $32(55.2)$ & $9(15.5)$ & 0.60 \\
\hline Cleft lip and palate & $260(55.8)$ & $206(44.2)$ & $63(27.0)$ & $134(57.5)$ & $36(15.5)$ & 0.07 \\
\hline Cleft palate only & $58(56.9)$ & $44(43.1)$ & $15(29.4)$ & $28(54.9)$ & $8(15.7)$ & 0.66 \\
\hline \multicolumn{7}{|l|}{ Cleft side } \\
\hline Bilateral & $95(57.9)$ & $69(42.1)$ & $24(29.3)$ & $47(57.3)$ & $11(13.4)$ & 0.30 \\
\hline Unilateral left & $160(54.8)$ & $132(45.2)$ & $39(26.7)$ & $82(56.2)$ & $25(17.1)$ & 0.21 \\
\hline Unilateral right & $71(56.3)$ & $55(43.7)$ & $17(27.0)$ & $37(58.7)$ & $9(14.3)$ & 0.29 \\
\hline \multicolumn{7}{|c|}{ Subgroups (only NSCL/P) } \\
\hline \multicolumn{7}{|c|}{ Mother smoking during pregnancy } \\
\hline No & $305(55.3)$ & $247(44.7)$ & $77(27.9)$ & $151(54.7)$ & $48(17.4)$ & 0.07 \\
\hline Yes & $78(60.9)$ & $50(39.1)$ & $18(28.1)$ & $42(65.6)$ & $4(6.3)$ & \\
\hline \multicolumn{7}{|c|}{ Alcohol consumption during pregnancy } \\
\hline No & $348(56.7)$ & $266(43.3)$ & $89(29.0)$ & $170(55.4)$ & $48(15.6)$ & 0.28 \\
\hline Yes & $35(53.0)$ & $31(47.0)$ & $6(18.2)$ & $23(69.7)$ & $4(12.1)$ & \\
\hline
\end{tabular}




\section{Resumo}

0 objetivo desse estudo foi avaliar a associação entre os polimorfismos no gene TCN2 (rs1801198) e no gene MTRR (rs1801394) com fissura de lábio e/ou palato não sindrômica (NSFL/P) em uma população brasileira. DNA genômico foi extraído de células bucais. Os polimorfismos nos genes TCN2 (rs1801198) e MTRR (rs1801394) foram genotipados através do PCR em tempo real pelo método Taqman. 0 teste do qui-quadrado foi utilizado para determinar a associação entre a frequência alélica e genotípica e NSFL/P e nos subtipos (fissura de lábio, fissura de lábio com palato e fissura de palato). Oitocentos e sessenta e sete indivíduos não aparentados (401 casos com NSFL/P e 466 indivíduos sem fissura) foram avaliados. A distribuição dos genótipos dos polimorfismos de TCN2 e MTRR estavam em equilibrio de Hardy-Weinberg. 0 genótipo polimórfico GG do gene TCN2 foi identificado em 16,7\% do grupo com NSFL/P e em $14,1 \%$ do grupo sem fissura $(p>0,05)$. Da mesma forma, a freqüência do genótipo GG do gene MTRR foi bastante semelhante entre o grupo com $\operatorname{NSFL/P}(15,5 \%)$ e o grupo controle $(17,8 \%)$. A análise multivariada mostrou associação entre o gene MTRR e o subgrupo que apresentou tabagismo materno durante a gestação $(p=0,039)$. Nossos resultados mostraram que não há associação entre os polimorfismos nos genes TCN2 e NSFL/P, entretanto sugerem uma associação entre MTRR e a etiologia de NSFL/P.

\section{Acknowledgements}

The authors are grateful to volunteers (subjects and their parents or guardians) of this study and the Nossa Senhora do Loreto Hospital, Ilha do Governador, Rio de Janeiro, Brazil and Professor Ronir Raggio Luiz (Institute of Public Health Studies, Federal University of Rio de Janeiro, Rio de Janeiro, RJ, Brazil). Funding resources from FDECIT-MS, FAPERJ and $\mathrm{CNPq}$ (Brazilian funding agencies) and individual fellowships from CNPq (ECK), CAPES (MWZ), UFF (TCSV) and FAPERJ (JMG) supported this work.

\section{References}

1. Vieira AR. Unraveling human cleft lip and palate research. J Dent Res, 2008;2:119-125.

2. Badovinac RL, Werler MM, Williams PL, Kelsey KT, Hayes C. Folic acidcontaining supplement consumption during pregnancy and risk for oral clefts: a meta-analysis. Birth Defects Res A Clin Mol Teratol 2007;1:815

3. Yoneda T, Pratt RM. Vitamin B6 reduces cortisone-induced cleft palate in the mouse. Teratology 1982;3:255-258.

4. He W, Meng T, Lu SJ, Zheng 0 , Li CH, Wu M, et al.. Vitamin B12 counteracts dexamethasone-induced proliferation and apoptosis during key periods of palatogenesis in mice. Ann Plast Surg 2010;4:466-470.

5. Carmel R. Measuring and interpreting holo-transcobalamin (holotranscobalamin II). Clin Chem 2002;3:407-409.

6. Herrmann W, Schorr H, Obeid R, Geisel J. Vitamin B-12 status, particularly holotranscobalamin II and methylmalonic acid concentrations, and hyperhomocysteinemia in vegetarians. Am J Clin Nutr 2003;1:131-136.

7. Lloyd-Wright Z, Hvas AM, Moller J, Sanders TA, Nexo E. Holotranscobalamin as an indicator of dietary vitamin B12 deficiency. Clin Chem 2003;12:2076-2078.

8. Nexo E, Christensen AL, Hvas AM, Petersen TE, Fedosov SN. Quantification of holo-transcobalamin, a marker of vitamin B12 deficiency. Clin Chem 2002;3:561-562.

9. Andres $E$, Loukili NH, Noel E, Kaltenbach G, Abdelgheni MB, Perrin AE et al.. Vitamin B12 (cobalamin) deficiency in elderly patients. Cmaj $2004 ; 3: 251-259$.
10. Boyles AL, Wilcox AJ, Taylor JA, Klaus Meyer, Åse Fredriksen, Per Magne Ueland, et al.. Folate and one-carbon metabolism gene polymorphisms and their associations with oral facial clefts. Am J Med Genet A 2008;4:440-449.

11. Martinelli M, Scapoli L, Palmieri A, Furio Pezzetti, Ugo Baciliero, Ernesto Padula, et al.. Study of four genes belonging to the folate pathway: transcobalamin 2 is involved in the onset of non-syndromic cleft lip with or without cleft palate. Hum Mutat 2006;3:294.

12. Guéant JL, Chabi NW, Guéant-Rodriguez RM, Mutchinick OM, Debard $\mathrm{R}$, Payet $\mathrm{C}$, et al.. Environmental influence on the worldwide prevalence of a $776 \mathrm{C}->\mathrm{G}$ variant in the transcobalamin gene (TCN2). J Med Genet, 2007:363-367.

13. Gueant-Rodriguez RM, Rendeli C, Namour B, Osvaldo M Mutchinick, Renée Debard, Corinne Payet, et al.. Transcobalamin and methionine synthase reductase mutated polymorphisms aggravate the risk of neural tube defects in humans. Neurosci Lett 2003;6:189-192.

14. Chorna LB, Akopian HR, Makukh HV, Fedoryk IM. Allelic polymorphism of MTHFR, MTR and MTRR genes in patients with cleft lip and/or palate and their mothers. Tsitol Genet 2011;3:51-56.

15. van der Linden IJ, den Heijer M, Afman LA, Henkjan Gellekink, Sita H. H. M. Vermeulen, Leo A. J. Kluijtmans, et al.. The methionine synthase reductase $66 \mathrm{~A}>\mathrm{G}$ polymorphism is a maternal risk factor for spina bifida. J Mol Med 2006;12:1047-1054.

16. Olteanu $H$, Munson $T$, Banerjee R. Differences in the efficiency of reductive activation of methionine synthase and exogenous electron acceptors between the common polymorphic variants of human methionine synthase reductase. Biochemistry 2002;45:13378-13385.

17. Brouns R, Ursem N, Lindemans J, Hop W, Pluijm S, Steegers E et al.. Polymorphisms in genes related to folate and cobalamin metabolism and the associations with complex birth defects. Prenat Diagn 2008;6:485-493.

18. Shaw GM, Carmichael SL, Laurent C, Rasmussen SA. Maternal nutrient intakes and risk of orofacial clefts. Epidemiology, 2006;3:285-291.

19. Kuchler EC, Tannure PN, Falagan-Lotsch P, Lopes TS, Granjeiro JM, Amorim LM. Buccal cells DNA extraction to obtain high quality human genomic DNA suitable for polymorphism genotyping by PCR-RFLP and Real-Time PCR. J Appl Oral Sci 2012;20:467-471.

20. De-Regil LM, Fernandez-Gaxiola AC, Dowswell T, Pena-Rosas JP. Effects and safety of periconceptional folate supplementation for preventing birth defects. Cochrane Database Syst Rev 2010;10:CD007950.

21. Mills JL, Molloy AM, Parle-McDermott A, Troendle JF, Brody LC, Conley $M R$, et al.. Folate-related gene polymorphisms as risk factors for cleft lip and cleft palate. Birth Defects Res A Clin Mol Teratol 2008;9:636643.

22. Mostowska A, Hozyasz KK, Wojcicki P, Dziegelewska M, Jagodzinski PP. Associations of folate and choline metabolism gene polymorphisms with orofacial clefts. J Med Genet 2010;12:809-815.

23. Brandalize AP, Bandinelli E, Borba JB, Felix TM, Roisenberg I, SchulerFaccini L. Polymorphisms in genes MTHFR, MTR and MTRR are not risk factors for cleft lip/palate in South Brazil. Braz J Med Biol Res 2007;6:787-791.

24. Northrop-Clewes CA, Thurnham DI. Monitoring micronutrients in cigarette smokers. Clin Chim Acta, 2007;1-2:14-38.

25. Vardavas $\mathrm{Cl}$, Linardakis MK, Hatzis $\mathrm{CM}$, Malliaraki N, Saris WH, Kafatos AG. Smoking status in relation to serum folate and dietary vitamin intake. Tob Induc Dis, 2008:8. 